\title{
SYNTHESIS AND STUDIES ON AROMATIC COPOLYESTER WITH ANTICANCER ACTIVITY DERIVED FROM 4,4'- DIHYDROXYBIPHENYL AND 3,5-DIHYDROXYTOLUENE
}

\author{
T. Sivaramakrishnan ${ }^{1, \bowtie}$ and G. Elango ${ }^{2}$ \\ ${ }^{1}$ PG \& Research Department of Chemistry, Ramakrishna Mission Vivekananda College, \\ Chennai-600004, (Tamil Nadu) India \\ ${ }^{2} \mathrm{PG} \&$ Research Department of Chemistry, Government Arts College, \\ Tiruvannamalai-606603, (Tamil Nadu) India \\ ${ }^{\square}$ Corresponding Author: sisa29@gmail.com
}

\begin{abstract}
In this investigation, a new wholly aromatic random copolyester containing 4,4'-dihydroxybiphenyl, 3,5dihydroxytoluene and Isophthaloyl chloride was synthesized using the solution polycondensation methodology in the mole ratio 2:1:3 and its solubility along with inherent viscosity were determined. The chemical structure of the copolyester was established by traditional spectroscopic techniques. The physical parameters of the polyester were studied employing WAXD studies and the thermal stability along with phase transitions were investigated employing TGA and DSC data. The morphological features in the polyester were probed using Scanning Electron Microscopy. The anticancer activity of copolyester was verified using HeLa (Cervical carcinoma) cell line employing MTT assay. Keywords: 3,5-dihydroxytoluene, 4,4'-dihydroxybiphenyl, MTT, Scanning Electron Microscopy, Copolyester, Polycondensation
\end{abstract}

RASĀYAN J. Chem., Vol. 14, No.4, 2021

\section{INTRODUCTION}

Aromatic polyesters are renowned for their notable thermal performance and good processibility. ${ }^{1-3}$ They possess exceptional thermal and mechanical properties and are widely exploited as engineering plastics. Lately, numerous research articles have focused on creating high-performance macromolecules involving Isophthaloyl group in the polymer backbone with a wide variety of aromatic diols as they possess phenomenal properties providing a wide scope of utilizations. ${ }^{4,5}$ In the last few decades, it has drawn much attention from researchers to produce new copolyesters containing isophthalate and terephthalate units which have been described to become less likely to crystallizable perfectly coupled with dropping melting temperatures due to the association with isophthalate units. ${ }^{6}$. Modification in tensile strength, thermal and mechanical properties due to induction of isophthalate portions into the backbone of terephthalate polyesters has been reported by Karayannidis, G.P. et al. ${ }^{7}$ Exceedingly sluggish crystallizing behavior leading to the development of lamellar crystals owing to lower nuclei density has been observed in entirely bio-based butylene isophthalate polyester. ${ }^{8}$ Recently, an ester-ester exchange reaction between poly $(1,12$ dodecamethylene isophthalate) and poly( $\varepsilon$-caprolactone) leading to the formation of a copolymer at elevated temperature has been documented. ${ }^{9}$ The incorporation of dimethyl isophthalate units caused improvement in glass transition temperature and augmented the thermal stability, optical characteristics and the gas barrier property in high molar mass butylene carbonate-co-isophthalate polyesters. ${ }^{10}$ The thermal changes and melt birefringence property in thermotropic copolyesters prepared by melt polycondensation based on 4,4'-biphenol and bisphenol A has been explored by Tsai, H. B. et al. ${ }^{11}$ Effects of flexible and rigid spacers in the formation of mesophases among polyesters based on 4,4'-dihydroxy biphenyl have been extensively studied by Wale, A. et al. ${ }^{12} \mathrm{Kim}, \mathrm{K}$. H. et al successfully studied the effects of attached quaternary salt structure and the effect of polymer catalysts on aromatic polyesters containing Isophthaloyl chloride and Diphenolic acid in the polycondensation reaction in aqueous and organic phases. ${ }^{13}$ Interfacial polymerization involving phase-transfer reaction of biphenyl derivative and Isophthaloyl chloride resulted in amorphous aromatic polyesters connected to biphenyl units in the side chain whose early degradation

Rasayan J. Chem., 14(4), 2428-2435(2021)

http://doi.org/10.31788/RJC.2021.1446544

This work is licensed under a CC BY 4.0 license. 
temperatures were observed around $450^{\circ} \mathrm{C} .{ }^{14}$ Innovative polyesters have been obtained from monomers containing substituted benzylidene cyclopentanone units with Isophthaloyl and Terephthaloyl dichlorides using interfacial polycondensation technique by Abd-Alla, M. A. et al. ${ }^{15}$ High-temperature solution methodology has been utilized to obtain novel polyarylates, which are thermally stable up to $350^{\circ} \mathrm{C}$ derived from hydroxy diphenylethylene derivatives along with aryl dicarboxylic acid chlorides by Watanabe, S. et al. ${ }^{16}$ Series of aromatic polyesters have been synthesized exploiting the solution polycondensation route involving Isophthalic acid with monomers containing dicyanovinyl substituents. ${ }^{17}$ Relatively new aromatic copolyesters synthesized from 5-(propargyloxy) isophthaloyl chloride and bisphenol A have displayed 10\% weight loss around $400^{\circ} \mathrm{C}$ validating their superior thermal stability. ${ }^{18}$ Analogy between polyesters derived from Terephthaloyl dichloride and Isophthaloyl dichloride along with hindered Biphenols and bulky substituent bearing Hydroquinones has revealed that polyesters obtained from Isophthaloyl dichloride exhibit better solubility and lower glass transition temperatures. ${ }^{19}$ High molecular weight crystalline aromatic copolyesters obtained from bisphenols containing pendant, Quinoxaline moiety by polymerization with Isophthaloyl chloride are reported to be thermally stable. ${ }^{20}$ With this knowledge in mind, in this paper, we synthesized a novel copolyester containing 4,4'-dihydroxybiphenyl and 3,5-dihydroxytoluene in the main chain along with Isophthalate units and analyzed the polymer highlighting the thermal stability with the aid of Thermogravimetric analysis and also its anticancer activity via MTT assay.

\section{Material and Methods}

\section{EXPERIMENTAL}

Merck samples of Isophthaloyl chloride, 3,5-dihydroxytoluene and 4,4'-dihydroxybiphenyl (Avra synthesis Private Limited) were used. AnalaR grade chemicals and solvents were employed in work. A viscosity study was done using Ubbelohde viscometer. Electronic spectrum was recorded in Shimadzu-UV-160A spectrophotometer utilizing propanone as solvent and FTIR spectrum of the polyester was obtained (Bruker FTIR Spectrometer) using $\mathrm{KBr}$ pellets. Jeol 500 spectrometer employing $\mathrm{CDCl}_{3}$ as solvent was utilized to record ${ }^{1} \mathrm{H}$ NMR spectrum. Thermogravimetric analysis was performed in Nitrogen environment employing SDT Q600 thermal analyzer and DSC thermogram of the polyester was recorded using NETZSCH STA449F3 Jupiter instrument. Wide Angle X-ray Diffraction studies were done by means of X'Pert Pro PW 3050 diffractometer $(\mathrm{Cu} \mathrm{k \alpha}, \lambda=1.5406 \AA), 2 \theta$ ranging from $10^{\circ}$ to $80^{\circ}$. SEM Micrographs were obtained using Tescan Vega $3(30 \mathrm{kV}$ - accelerating voltage). Anti-proliferative studies of the copolyester was investigated using HeLa cell line (MTT method).

\section{Procedure for Synthesis of Copolyester (PTBI)}

Poly(3-oxy-5-methylphenyl(4'-oxy-[1,1'-biphenyl]-4-yl)isophthalate was prepared by reacting 4,4'dihydroxy biphenyl $(3.724 \mathrm{~g}, 0.02 \mathrm{~mol})$ with 3,5 -dihydroxy toluene $(1.241 \mathrm{~g}, 0.01 \mathrm{~mol})$ using about $150 \mathrm{~mL}$ of 1,2-dichlorobenzene as solvent in to which Isophthaloyl chloride $(6.09 \mathrm{~g}, 0.03 \mathrm{~mol})$ was added for solution polycondensation process. The detailed procedure of preparation of polyesters has been reported previously. ${ }^{21}$ The contents were agitated for about $50 \mathrm{~h}$ at $150^{\circ} \mathrm{C}$ in Nitrogen atmosphere and cooled, poured into about $300 \mathrm{~mL}$ of petroleum ether and kept overnight in a refrigerator followed by filtration; this procedure adopted is similar to earlier report. ${ }^{22}$ The crude polyester was primarily rinsed with double distilled water, then in Propanone before finally pouring into distilled water. The resultant mixture was ultimately vaporized and dried in a vacuum over Phosphorous pentoxide to obtain the pure polyester with a yield of around $70 \%$. This polyester was prepared in appropriate yield under the reaction conditions, which was better than the other polymers prepared under various experimental conditions, which are not discussed here. The molecular structures and the scheme of preparation are illustrated (Scheme- 1).

\section{Inherent Viscosity and Solubility of the Copolyester}

\section{RESULTS AND DISCUSSION}

The copolyester was found to be freely soluble in Propanone and also soluble in Chloroform, DMF and oChloro Phenol. This may be due to the interactions of the polar solvents with the ester linkages in the polyester. The polymer was found to be almost similar in solubility in DMSO, Methanol and THF which 
RASĀYAN J. Chem.

Vol. 14 | No. 4 |2428-2435| October-December | 2021

may be due to secondary bonding interactions between solvent and the polymer. The conformation of biphenyl aromatic units influencing inter chain interactions and disrupting the orderliness of the substituents along the polyester backbone is reported in literature. ${ }^{23}$ The viscosity $\left(\eta_{\text {inh }}\right)$ of the polymer was assessed using relative viscosity values derived by comparing the flow time of the polyester solution along with solvent (o-Chlorophenol) using Ubbelohde viscometer (concentration $=0.1 \mathrm{~g} / \mathrm{dL}$ at $30^{\circ} \mathrm{C}$ ) was found to be $0.31 \mathrm{dL} / \mathrm{g}$. Ping, Z. et al have reported lower viscosity values for aromatic polyesters prepared using Isophthaloyl chloride and esters of diphenolic acid. ${ }^{24}$

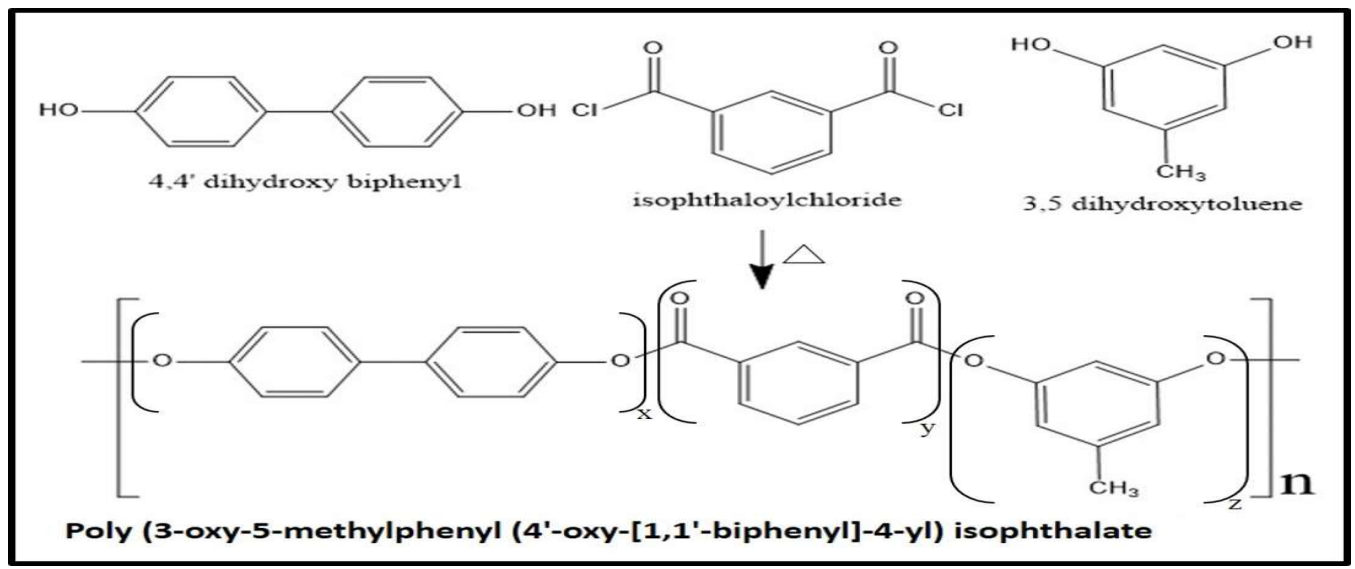

\section{Spectral Studies}

Scheme-1

\section{UV-Visible Spectrum}

The electronic absorption spectroscopy is principally operated to investigate the chromophoric moieties or the extended conjugation present in the aromatic system of polymers. ${ }^{25}$ The UV-Visible electronic spectrum of PTBI recorded with a concentration of $10^{-5} \mathrm{M}$ in Propanone as solvent depicted in Fig.-1 shows a broadband around $280 \mathrm{~nm}$, which is ascribed to the aromatic chromophores in the polyester.

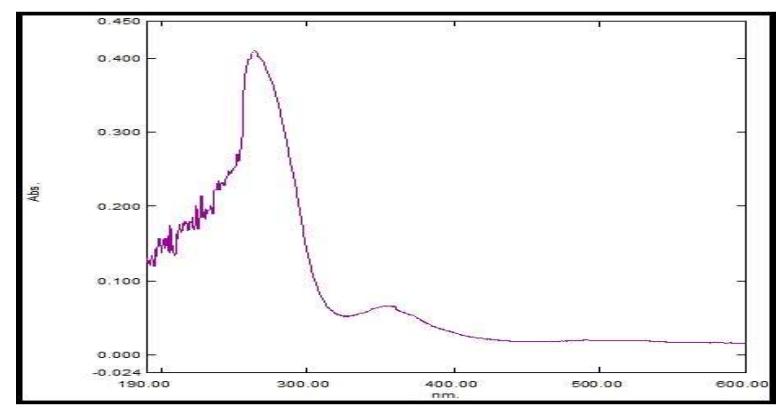

Fig.-1: UV-Visible Spectrum of PTBI

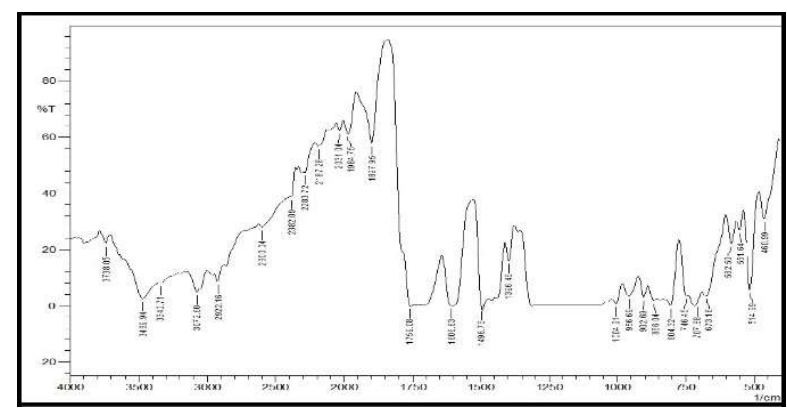

Fig.-2: FTIR Spectrum of PTBI

\section{FTIR Spectrum}

The repeat structure and the functional group present in the polyester were confirmed by FTIR spectral data. Figure 2 shows the characteristic FTIR spectrum of the polyester PTBI. Some characteristic absorptions appeared in the spectrum, such as C-H stretching near $2900 \mathrm{~cm}^{-1}{ }^{26}$ The copolyester shows distinctive carbonyl stretching absorption bands of the ester group near $1760 \mathrm{~cm}^{-1}$, substantiating the presence of ester linkages in the polyester. The band near $1230 \mathrm{~cm}^{-1}$ (ester C-O stretching) also validates the presence of ester moieties in the polymer sample, as reported by Kandaswamy, N. ${ }^{27}$ The broad detectable band around $3469 \mathrm{~cm}^{-1}$, due to hydroxyl group stretching vibration, is also observed. ${ }^{28}$ Bands occurring below $866 \mathrm{~cm}^{-1}$ reveal $\mathrm{C}-\mathrm{H}$ bending vibrations and the aromatic ring stretch is illustrated by absorption at $1608 \mathrm{~cm}^{-1}$ and $1496 \mathrm{~cm}^{-1}$ in the FTIR spectrum. 


\section{${ }^{1}$ H NMR Spectrum}

The structure of the prepared polyester backbone was confirmed by ${ }^{1} \mathrm{H}-\mathrm{NMR}$ spectrum (Fig.-3) employing $\mathrm{CDCl}_{3}$ as solvent. The signals of methyl protons of 3,5-dihydroxytoluene units in the polyester sequence were assigned to the resonances in the range 1.1 to $2.6 \mathrm{ppm} .{ }^{29}$ The resonances ranging from 6.8 to $9.2 \mathrm{ppm}$ were attributed to the aryl protons of all the monomers involved in the polymer structure. ${ }^{30}$

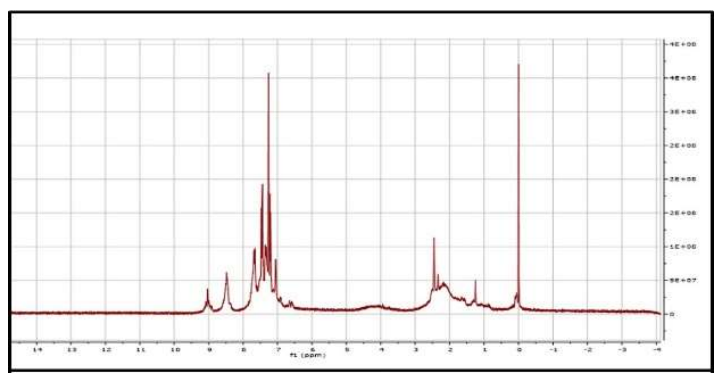

Fig.-3: ${ }^{1} \mathrm{H}$ Spectrum of PTBI

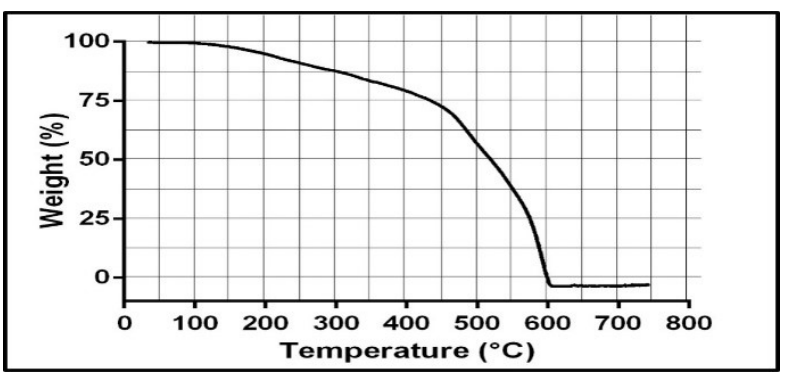

Fig.-4: TGA Thermogram of PTBI

\section{Thermogravimetric Analysis (TGA)}

It is observed that copolyesters containing aliphatic groups in the main chain are thermally less stable compared to those with aromatic groups in the backbone of the polymer. ${ }^{31}$ Thermal studies on the copolyester were performed via Thermogravimetric analysis (TGA) in $\mathrm{N}_{2}$ environment when the sample was subjected to heating starting from 60 to $800^{\circ} \mathrm{C}$ (heating rate of $20^{\circ} \mathrm{Cmin}^{-1}$ ) is depicted in Figure 4. The polymer shows initial decomposition temperature at $350^{\circ} \mathrm{C}$ and char yield was found to be at $600^{\circ} \mathrm{C}$. From this, it was shown that the synthesized polyester was found to be thermally stable at $350^{\circ} \mathrm{C}$, which could be due to the aromatic rings present in the polymeric chain as indicated by similar studies reported in the literature for thermal decomposition of polyesters. ${ }^{32,33}$

\section{Differential Scanning Calorimetry (DSC)}

The thermogram (Fig.-5) reveals the commencement of $\mathrm{T}_{\mathrm{g}}$ at $80.9^{\circ} \mathrm{C}$ and also multiple peaks are observed at $269.7^{\circ} \mathrm{C}, 292.7^{\circ} \mathrm{C}$ and $330^{\circ} \mathrm{C}$ with enthalpy of melting being $18.07 \mathrm{~J} / \mathrm{g}$. Aromatic polyesters comprising of suspended carboxyl groups derived from Isophthaloyl chloride have been reported to possess glass transition temperatures in the range 79 to $96^{\circ} \mathrm{C}$ which is in harmony with the results obtained in the DSC thermogram. ${ }^{34}$ Simitzis, J. et al have observed that the parameters achieved from the results in the DSC scan vary with the nature and proportion of the comonomers in the specific polyesters, presence or absence of catalyst during the polyesterification process. ${ }^{35}$ Reports on aromatic polyesters derived from Terephthaloyl chloride possessing rigid p-phenylene groups displayed higher values of $\mathrm{T}_{\mathrm{g}}$ compared to those resulting from Isophthaloyl chloride containing comparatively less rigid, the symmetric orientation of the m-phenylene groups in the polymer chain are available in literature. ${ }^{21}$

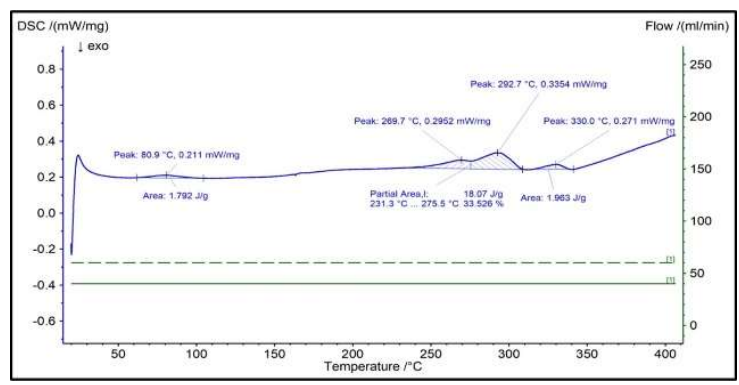

Fig.-5: DSC Thermogram of PTBI

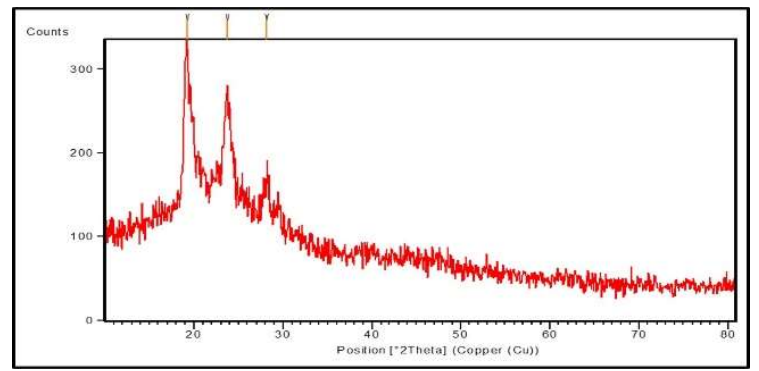

Fig.-6: X-ray Diffraction Pattern of PTBI 


\section{Wide-angle X-ray Diffraction (WAXD)}

The WAXD powder pattern of copolyester PTBI, presented in Figure 6, indicates the polyester to be semicrystalline in nature, as reported by Jadhav, S. A. et al, among polyesters synthesized from Isophthaloyl chloride. ${ }^{36}$ This may be due to the occurrence of polar ester moieties influencing the crystalline nature of the copolyester ${ }^{37}$ The polyester sample revealed a prominent reflection with maxima at $2 \theta=19.2569^{\circ}$, height (cts) 222.08 , corresponding to $d$ value $4.60927 \AA$. Peaks at $2 \theta$ values ranging from 23.7923 to 28.1368 with interplanar spacing in the range 3.73990 to $3.17154 \AA$ were also observed in the copolyester.

\section{Scanning Electron Microscopy (SEM)}

In the literature, it has been reported that the SEM pictures can reveal vital information regarding the morphology and crystal formations between the fibers in aromatic polyesters. ${ }^{38}$ The comparison of the SEM micrographs of the copolyester PTBI (Fig.-7) with the reports on aromatic polyesters by Jasinski, W. et al show resemblances in the presence of nodules and holes. ${ }^{39}$ The fracture texture and cracks which are apparent throughout the surface of the polyester sample are analogous to previous reports in the literature. ${ }^{40}$
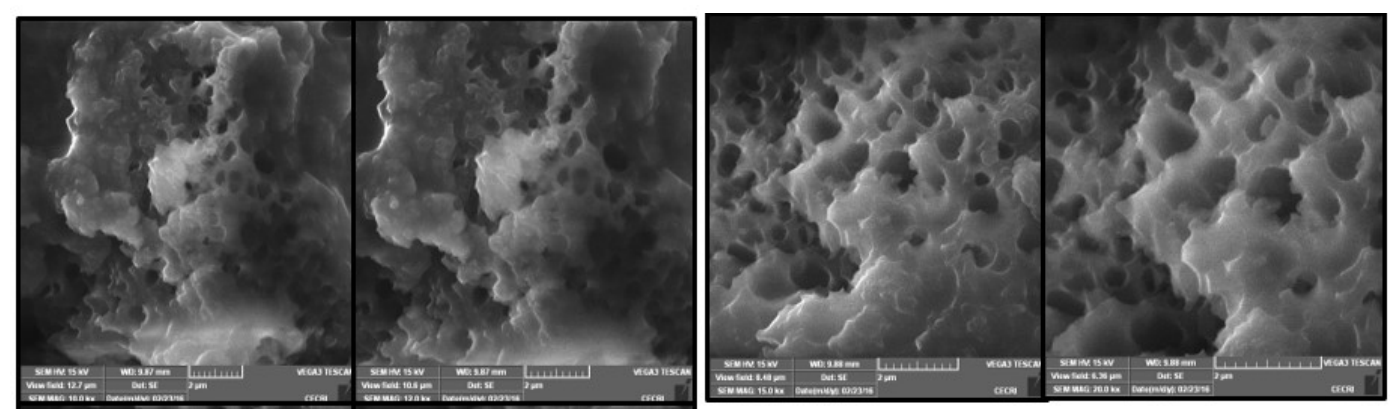

Fig.-7: SEM Micrographs of PTBI

\section{Anticancer Study}

MTT Assay

Antiproliferative effects and studies on cytotoxicity of aliphatic copolyesters are found in the literature. ${ }^{41,42}$ The MTT analysis on cytotoxicity using HeLa cell viability based on products formed from polyester hydrolysis has been analyzed in detail by Kim, M. N. et al. ${ }^{43}$ In the present study on the aromatic copolyester, PTBI was analyzed employing HeLa (Cervical carcinoma) cell line following MTT assay with the routine procedure, the cells were seeded in 96 wells were cultured at $37^{\circ} \mathrm{C}$ along with $5 \% \mathrm{CO}_{2}$. The given polyester samples in DMSO solution were diluted to 100 to $50 \mu \mathrm{g} / \mathrm{mL}$ with DMEM and were added to every culture well at a concentration of $50 \mu \mathrm{M}$ and incubated for $24 \mathrm{~h}$. The supernatant was separated and the residues were dissolved in DMSO after the addition of $20 \mu 1$ of MTT $(5 \mathrm{mg} / \mathrm{mL})$ to each culture well. Subsequently, the reduction of MTT was computed by measuring the absorbance at $570 \mathrm{~nm}$. The formula used to estimate the $\%$ of viable cells was:

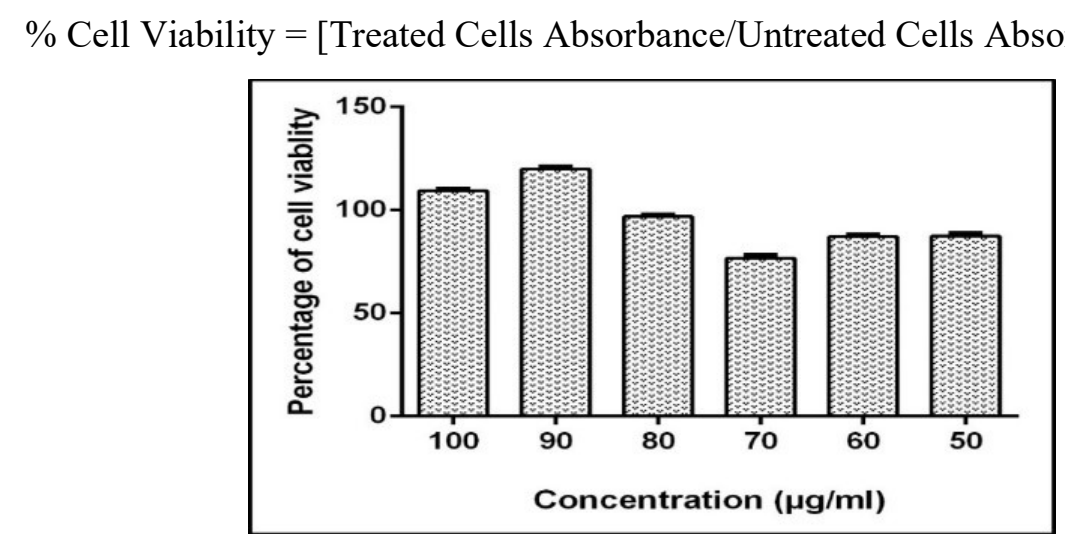

Fig.-8: Cell Viability of PTBI 
In HeLa cell line, 50, $60 \mu \mathrm{g} / \mathrm{mL}$ concentrations revealed 75 to $80 \%$ cell viability, whereas $70 \mu \mathrm{g} / \mathrm{mL}$ concentration resulted in the percentage of cell viability ranging from 65 to $75 \%$ as displayed in Figure 8 . The other concentrations of 80,90 and $100 \mu \mathrm{g} / \mathrm{mL}$ revealed cell viability ranging from 90 to $125 \%$. The polyester exhibited increased cell viability boosted by increment in concentration except for the concentration, $70 \mu \mathrm{g} / \mathrm{ml}$, which may act as a potential drug against the HeLa cell line.

\section{CONCLUSION}

The aromatic polyester was synthesized from 4,4'-dihydroxybiphenyl, 3,5-dihydroxytoluene and Isophthaloyl chloride employing a well-established, conventional polycondensation procedure. The copolyester showed better solubility in many well-known organic solvents such as Propanone and Chloroform, which is requisite for its diverse applications. The chemical structure of the recurring units in the synthesized polyester was ratified on the basis of standard spectroscopic techniques, namely UVVisible, FTIR and Proton Nuclear Magnetic Resonance. The thermal properties were summarized on the basis of TGA, indicating superior thermal stability up to $600^{\circ} \mathrm{C}$ and DSC thermograms revealing $\mathrm{T}_{\mathrm{g}}$ at $80.9^{\circ} \mathrm{C}$ and $\mathrm{T}_{\mathrm{m}}$ around $292.7^{\circ} \mathrm{C}$. From the WAXD study, it is disclosed that PTBI is semi-crystalline in nature, as expected based on earlier reports. The SEM micrographs revealed heterogeneous morphology with nodules and holes. The anticancer efficacy studies suggest that the copolyester PTBI displays potent anticancer activity at a concentration of $70 \mu \mathrm{g} / \mathrm{ml}$. The ratio of various diol concentrations in the polymer structure may influence the Anti-cancer activity. The work along this direction is in progress.

\section{ACKNOWLEDGEMENT}

The authors express thanks to SAIF, IIT Madras and C.I.S.L., Annamalai University, for furnishing spectral data and facilitating thermal studies.

\section{REFERENCES}

1. B. W. Liu, Y. F. Lei, X. F. Liu, D. M. Guo, L. Chen and Y. Z. Wang, Polymer, 218, 123430(2021), https://doi.org/10.1016/j.polymer.2021.123430

2. P. Zhang, L. Wu, Z. Bu and B,-G. Li, Journal of Applied Polymer Science, 108, 3586(2008), https://doi.org/10.1002/app.27959

3. C. R. Arza and B. Zhang, ACS Omega, 4(12), 15012(2019), https://doi.org/10.1021/acsomega.9b01802

4. A. Muthusamy, K. Balaji, S. C. Murugavel, C. Yuan and L. Dai, Polymer Science, Series B, 62(3), 245(2020), https://doi.org/10.1134/S1560090420030112

5. Y. Zhang, G. M. Yan, G. Zhang, S. L. Liu and J. Yang, Polymer, 186, 122047(2020), https://doi.org/10.1016/j.polymer.2019.122047

6. Li Baozhong, Yu Jiayan, Seungwoo Lee and Moonhor Ree, Polymer, 40(19), 5371(1999), https://doi.org/10.1016/S0032-3861(98)00743-5

7. G. P. Karayannidis, I.D. Sideridou, D. N. Zamboulis, D. N. Bikiaris and A. J. Sakalis, Journal of Applied Polymer Science, 78, 200-207(2000), https://doi.org/10.1002/10974628(20001003)78:1<200::AID-APP240>3.0.CO;2-R

8. S. Quattrosoldi, R. Androsch, A. Janke, M. Soccio and N. Lotti, Polymers, 12(1), 235(2020), https://doi.org/10.3390/polym12010235

9. T. Katoh, Y. Ogawa, Y. Ohta and T. Yokozawa, Journal of Polymer Science, 59(9), 787(2021), https://doi.org/10.1002/pol.20210032

10. K. H. Paek and S. G. Im, Green Chemistry, 22(14), 4570(2020), https://doi.org/10.1039/D0GC01549K

11. H. B.Tsai, C. Lee, N. S. Chang and A. T. Hu, Polymer Bulletin, 24(3), 293(1990), https://doi.org/10.1007/BF00306577

12. A. Wale, S. Mule, A. Dhage, K. Mulani, S. Ponrathnam and N. Chavan, Advanced Journal of Chemistry, Section A: Theoretical, Engineering and Applied Chemistry, 3(4), 510(2020), http://dx.doi.org/10.33945/SAMI/AJCA.2020.4.12

13. K. H. Kim, J. Y. Moon, D. H. Ha and D. W. Park, Reaction Kinetics and Catalysis Letters, 75(2), 385(2002), https://doi.org/10.1023/A:1015223718354 
RASĀYAN J. Chem.

Vol. 14 | No. 4 |2428-2435| October- December | 2021

14. P. N. Honkhambe, C. V. Avadhani, P. P. Wadgaonkar and M. M. Salunkhe, Journal of Applied Polymer Science, 106(5), 3105(2007), https://doi.org/10.1002/app.25862

15. M. A. Abd-Alla, M. M. Kandeel, K. I. Aly and A. S. Hammam, Journal of Macromolecular Science: Part A - Chemistry, 27(5), 523(1990), https://doi.org/10.1080/00222339009349640

16. S. Watanabe, A. Kobayashi, M. A. Kakimoto and Y. Imai, Journal of Polymer Science Part A: Polymer Chemistry, 32(5), 909(1994), https://doi.org/10.1002/pola.1994.080320512

17. N. Kawatsuki, M. Dörr and H. W. Schmidt, Journal of Polymer Science Part A: Polymer Chemistry, 31(4), 1013(1993), https://doi.org/10.1002/pola.1993.080310423

18. S. Verma, D. M. Maher, S. S. Nagane, B. V. Tawade and P. P. Wadgaonkar, Journal of Polymer Science Part A: Polymer Chemistry, 57(5), 588(2019), https://doi.org/10.1002/pola.29297

19. W. G. Kim and A. S. Hay, Journal of Polymer Science Part A: Polymer Chemistry, 32(1), 97(1994), https://doi.org/10.1002/pola.1994.080320111

20. V. B. Patil, M. Medhi, N. S. Bhairamadgi, P.P. Wadgaonkar and N. N. Maldar, Materials Science and Engineering: B, 168(1-3), 186(2010), https://doi.org/10.1016/j.mseb.2009.12.036

21. D. J. Liaw, B. Y. Liaw, J. J. Hsu and Y. C. Cheng, Journal of Polymer Science Part A: Polymer Chemistry, 38(24), 4451(2000), https://doi.org/10.1002/1099-0518(20001215)38:24\%3C4451::AIDPOLA140\%3E3.0.CO;2-Q

22. S. S. Nagane, S. S. Kuhire, U.A. Jadhav, S. A. Dhanmane and P. P. Wadgaonkar, Journal of Polymer Science Part A: Polymer Chemistry, 57(5), 630(2019), https://doi.org/10.1002/pola.29303

23. H. W. Schmidt and D. Guo, Die Makromolekulare Chemie: Macromolecular Chemistry and Physics, 189(9), 2029(1988), https://doi.org/10.1002/macp.1988.021890906

24. Z. Ping, W. Linbo and L. Bo-Geng, Polymer Degradation and Stability, 94(8), 1261(2009), https://doi.org/10.1016/i.polymdegradstab.2009.04.015

25. K. Fatima, A. Gul, Z. Akhter and R. Rahman, Journal of Inorganic and Organometallic Polymers and Materials, 27(2), 474(2017), https://doi.org/10.1007/s10904-016-0489-1

26. S. Cheng, M. Rabnawaz, F. Khan and B. Khan, Journal of Applied Polymer Science, 136(11), 47200(2019), https://doi.org/10.1002/app.47200

27. N. Kandaswamy, Macromolecular Research, 27(6), 593(2019), https://doi.org/10.1007/s13233-0197082-8

28. Y. Chebbi, N. Kasmi, M. Majdoub, P. Cerruti, G. Scarinzi, M. Malinconico, G. D. Poggetto, G. Z. Papageorgiou and D. N. Bikiaris, ACS Sustainable Chemistry \& Engineering, 7(5), 5501(2019), https://doi.org/10.1021/acssuschemeng.8b06796

29. Y. Nakayama, W. Yagumo, R. Tanaka, T. Shiono, K. Inumaru, C. Tsutsumi, N. Kawasaki, N. Yamano, and A. Nakayama, Polymer Degradation and Stability, 174, 109095(2020), https://doi.org/10.1016/j.polymdegradstab.2020.109095

30. N. Kasmi, Z. Terzopoulou, G. Z. Papageorgiou and D. N. Bikiaris, Express Polymer Letters, 12(3), 227(2018), https://doi.org/10.3144/expresspolymlett.2018.21

31. M. S. Abdelaty, American Journal of Polymer Science and Technology, 3(1), 12(2017), https://doi.org/10.11648/j.ajpst.20170301.12

32. S. S. Nagane, S. Verma, B. V. Tawade, P.S. Sane, S. A. Dhanmane, and P.P. Wadgaonkar, European Polymer Journal, 116, 180(2019), https://doi.org/10.1016/j.eurpolymj.2019.04.019

33. A. Chowdhury, S. K. Singh, S. Marker and P. Anthony, Rasayan Journal of Chemistry, 13(3), 1834(2020), http://dx.doi.org/10.31788/RJC.2020.1335875

34. D. W. Park, D. H. Ha, J. Y. Park, J. Y. Moon and H. S. Lee, Reaction Kinetics and Catalysis Letters, 72(2), 219(2001), https://doi.org/10.1023/A:1010522308098

35. J. Simitzis, L. Zoumpoulakis and S. Soulis, Polymer International, 51(4), 308(2002), https://doi.org/10.1002/pi.832

36. S. A. Jadhav, R. R. Chougule, Y. A. Shinde and N. N. Chavan, Journal of Applied Polymer Science, 103(2), 1232(2007), https://doi.org/10.1002/app.24610

37. R. Qu, C. Sun, C. Ji, C. Wang, H. Chen, Y. Niu, C. Liang and Q. Song, Carbohydrate Research, 343(2), 267(2008), https://doi.org/10.1016/j.carres.2007.10.032

2434

AROMATIC COPOLYESTER WITH ANTICANCER ACTIVITY

T. Sivaramakrishnan and G. Elango 
RASĀYAN J. Chem.

Vol. 14 | No. 4 |2428-2435| October- December | 2021

38. S. Ozden, A. M. Charayev and R. C. Bazheva, Journal of Applied Polymer Science, 111(4), 1755(2009), https://doi.org/10.1002/app.29147

39. W. Jasinski, V. Carlier, R. Legras and W. Mormann, Macromolecular Symposia, 198(1), 323(2003), https://doi.org/10.1002/masy.200350827

40. D. H. Weinkauf and D. R. Paul, Journal of Polymer Science Part B: Polymer Physics, 30(8), 837(1992), https://doi.org/10.1002/polb.1992.090300805

41. B. Yamini and R. Nanthini, Rasayan Journal of Chemistry, 11(1), 413(2018), http://dx.doi.org/10.7324/RJC.2018.1112002

42. B. Yamini and R. Nanthini, Rasayan Journal of Chemistry, 11(2), 440(2018), http://dx.doi.org/10.31788/RJC.2018.1121992

43. M. N. Kim, B. Y. Lee, I. M. Lee, H. S. Lee and J. S. Yoon, Journal of Environmental Science and Health, Part A, 36(4), 447(2001), https://doi.org/10.1081/ESE-100103475

[RJC-6544/2021] 